\title{
Film Analysis in Management Research: Knowing Why and How to Use It
}

\section{Análise Fílmica em Pesquisas em Administração: Sabendo o Porquê e Como Utilizá-la}

\author{
Nildes Raimunda Pitombo Leite ${ }^{i}$ \\ Orcid: https://orcid.org/0000-0003-0802-9628 \\ Augusto Takerissa Nishimura ${ }^{\text {iii }}$ \\ Orcid: https://orcid.org/0000-0001-8393-2978
}

\author{
Fábio Pitombo Leite ${ }^{\text {ii }}$ \\ Orcid: https://orcid.org/0000-0002-5827-5360
}

Marco Antonio Batista da Silva ${ }^{\text {iv }}$

Orcid: https://orcid.org/0000-0003-4616-4038

Emerson Gomes dos Santos ${ }^{v}$

Orcid: https://orcid.org/0000-0002-3037-5001

\begin{abstract}
Despite many recent peer-reviewed publications in scientific journals, broad understanding of the production of observational studies using film analysis seems to be lacking. This article reviews the increasing use of film analysis as a qualitative tool in the field of management studies, with particular attention paid to why and how to use it. Hence, this review addresses questions such as: What are these studies? What are the factors that should be considered for them to continue being produced? What are the possibilities of locus? How is scientific rigor contemplated? As a result, enhanced qualitative, descriptive, inductive, interpretive, and reflective understanding of its methodological aspects is expected. Its contribution can support researchers interested in producing observational studies in film analysis, considering the chosen locus, object, and specificities of each study whilst paying attention to the rigor of this research approach.
\end{abstract}

Keywords: film analysis; qualitative research; observational studies.

\begin{abstract}
Resumo
Apesar de muitas publicações recentes em revistas científicas, parece faltar um amplo entendimento da produção de estudos observacionais usando a análise fílmica. Este artigo revisa o uso crescente da análise fílmica como uma estratégia de pesquisa qualitativa no campo de estudos da administração, com atenção especial para o porquê e como utilizá-la. Assim, esta revisão inicia-se com questões como: O que são esses estudos? Quais são os fatores que devem ser considerados para que continuem sendo produzidos? Quais são as possibilidades de lócus? Como o rigor científico é contemplado? Como resultado, espera-se um melhor entendimento qualitativo, descritivo, indutivo, interpretativo e reflexivo de seus aspectos metodológicos. Sua contribuição pode apoiar pesquisadores interessados em produzir estudos observacionais em análise fílmica, atentando para o rigor dessa abordagem de pesquisa, aplicada no passo a passo específico de cada estudo e considerando o lócus e objeto de estudo escolhidos.
\end{abstract}

Palavras-chave: análise fílmica; pesquisa qualitativa; estudos observacionais.

\footnotetext{
${ }^{\text {i } U n i v e r s i d a d e ~ F e d e r a l ~ d e ~ S a ̃ o ~ P a u l o-U n i f e s p . ~ D e p a r t a m e n t o ~ d e ~ A d m i n i s t r a c ̧ a ̃ o, ~ E s c o l a ~ P a u l i s t a ~ d e ~ P o l i ́ t i c a, ~}$ Economia e Negócios, Campus Osasco, Brasil. E-mail: nildes.pitombo@unifesp.br

ii Department of Psychology, Lima Campus, The Ohio State University. E-mail: leite.11@osu.edu

iii Centro Universitário das Américas-FAM, São Paulo, Brasil. E-mail: nishi.adm@gmail.com

iv Instituto Federal de Educação, Ciência e Tecnologia do Sul de Minas Gerais-Campus Avançado Carmo de

Minas_IFSul de Minas, Brasil. E-mail: prof.marcoabs@gmail.com

v Departamento de Administração, Escola Paulista de Política, Economia e Negócios, Campus Osasco,

Universidade Federal de São Paulo_-Unifesp, Brasil. E-mail: emerson.gomes@unifesp.br
} 


\section{INTRODUCTION}

In the making of motion pictures and television series, a rich set of strategies involving camera angle and movement, sound and lighting effects, music, dialogue, and editing, among others, is used to maximize the intended effects onto their audience. Bringing the end products to use in the academic and scientific context, films and series can afford educators and researchers experiential and reflective opportunities that would otherwise be impractical. In the field of management in particular, film analysis can aid the inextricable relationship among teaching and learning, research, and extension (e.g., Leite, Leite, Nishimura \& Cherez, 2010).

In the years following Fleury and Sarsur (2007), Ipiranga (2007) and Leite and Leite (2007), there has been a marked increase in the use of film analysis to address a wide range of questions in the field of management, from strengthening organizational teams to power relations to organizational communication to sustainability (e.g., Bizarria, Tavares, Brasil, Tassigny, \& Silva, 2017; Freitas \& Leite, 2015; Leite \& Leite, 2010; Matos, Lima, \& Giesbrecht, 2011). Given both the observed rise and the expected continuing growth in the tool's utilization (Leite, Amaral, Freitas \& Alvarenga, 2012), this article reviews the contribution of film analysis. By discussing why, how, and when to use this qualitative tool, its aim is to provide academicians and practitioners in management sufficient information to know when to choose it and when not to choose it in the aid of research or practice questions at hand.

In the following sections, film analysis is contextualized and defined within observational studies, essential methodological steps are reviewed, and concluding remarks are offered. It is intended that the relevance of this article will lie in contributing to the elucidation of observational studies using film analysis in studies of management by reviewing its qualitative, descriptive, inductive, interpretive, and reflective potential.

\section{OBSERVATIONAL STUDIES}

Observational studies, in general, encompass a detailed examination of behaviors or activities that the researcher observes directly or indirectly through systematic or spontaneous observation protocols. Through observations, it is possible to attempt to understand the interactions, practices and events that take place in a given context. Observational studies provide specific access to engender the processes of constructing that understanding.

Following Denzin (1989) and Vanoye and Galiot-Lèté (1992), film analysis is a micro-analytic approach based on indirect and systematic observation. Thus, the observational studies using film analysis are characterized by indirect and non-participant observation, enabling collection and analysis of directly- and indirectly-observable data.

Compared to interview responses, Flick (2004) noted that the data obtained through the images of films and TV series allow access to the non-verbal component of language with the advantage of repeated access to all the data, making the transposition of the limitations of perception and documentation viable. Observing the need for distinction between video data produced by the researcher and information already available (e.g., Loizos, 2011), it is noted that the term film analysis is used throughout this article to describe analyses of commercial films (long or short) or series. With repeated access to the data both in the dialogues and non-verbal components (aided by images, lighting, colors and sounds), there is great versatility in film analysis to catalogue different symbols and decode them, favoring the elucidation of the behaviors observed in the characters-which should be behaviors that 
can often be observed in the group of interest (e.g., mentees, organizational team members).

The plurality of reading levels comprises an important characteristic of film analysis (Denzin, 1989; 2004). In this plurality, the realistic reading suggests the object of observation (film or series) as a true description of the treated phenomena, whose meanings are evidenced through detailed analysis of the contents and formal aspects of the images and other filmic languages. In interpretive reading, one does not speak about the universal features of human conditions, but about limited versions of human experience, given that the authors' ideas about reality influence the film or the series they are authoring, in the same way that the interpreters' ideas influence their interpretations.

Considering the potential use of film analysis beyond research, it can be used for/as (Champoux, 1999; Huczynski \& Buchanan, 2004): (1) experimental exercise on problem solving; (2) demonstration of metaphor or satire, in which the central themes are transformed into metaphorical examples; (3) interpretation or description of symbolism; (4) creating experiences for the introduction of a new perspective (or even a new culture); (5) a resource to address a historical issue or portraying specific eras; (6) case studies; and (7) reality reflections. For didactic functions, it can also be used as follows (Napolitano, 2013): in terms of content, (8) for generating text, based on the questions and themes raised; and, in terms of of language, (9) as observation, based on the narrative forms and expressive resources of these loci.

In the organizational context, for example, film analysis can facilitate the exploration of the dynamics of organizations, avoiding direct exposure of the people who make up the organization while facilitating their contribution to reflections that can assist in the process of solving real problems arising from these dynamics. When film analysis is used in the context of teaching and learning, at the undergraduate and graduate levels, it is worth heeding Vergara's (2007) advice for students to take care in using the film's content and form jointly, while preserving their intellectual independence. Adding extension efforts to teaching and research, the three are faces of equal importance within a unified project of ethical, epistemic, and political formation (Severino, 2016, p. 36).

Such possibilities of film analysis are consistent with Hucznski and Bucahanan's (2004) view about films being information-rich and far from neutral, akin to the way narratives contain embedded explanations for the events in addition to offering scenes for the interpretation of actions. From a similar perspective, Denzin (2004) considered the existence of four elements in a film: (1) the visual; (2) the auditory; (3) the narrative; and (4) the meanings of the observer, as each person interprets the set of scenes presented in a particular way. In other words, these four elements need to be seen according to the characteristics of each activity (viz., teaching and learning, research, extension) because both the time spent in observation and the consequent perceptions tend to be different in each one of them.

Research involving observational studies in film analysis in the area of management follows the same pattern inherent to the entire process of scientific research. Requirements for methodological rigor, such as transparency, credibility, consistency, reliability, and robustness (e.g., Chizzotti, 2008) apply. Because these requirements can be met with the tool's use, film analysis has been appreciated as an opportunity to initiate science and as a means to strengthen professional training.

\section{METHODOLOGICAL CONSIDERATIONS}

To begin addressing how scientific rigor is included in film analysis, consider Vanoye and Goliot-Lété's (2012, p.14) take 
that analyzing a film is about breaking it down into its constituent elements. In this decomposition, deconstruction is equivalent to description, while reconstruction is equivalent to interpretation, given that the film is both the starting point and the ending point of the analysis. Furthermore, it is necessary, to a large extent, to enjoy the analysis process itself, for film analysis requires time and perseverance.

It is argued elsewhere that film analysis in the field of management leads to the possibility of looking metaphorically at organizations, educational institutions, and the existing relationships between the various agents therein (e.g., Leite, Nishimura, Silva, \& Santos, 2021). As illustrated in Aoki and Santos (2020), the aim is then to maintain the inseparability between teaching, research, and extension through the creation or dissemination of knowledge, given the understanding that films or series share elements of real life.

\subsection{Qualitative and quantitative approaches}

According to Jones (2014), applying a quantitative approach to observations, researchers tend to support highly standardized forms and passive observer roles in order to maximize reliability and perceived validity of the recorded observations. This structured, systematic observation generally involves the collection of behavioral data through a standardized and predefined observation protocol. The observed behavior can occur in experimental conditions or in the natural organizational environment. In both situations, the protocol aims to ensure that any observer makes the same observations consistently, therefore controlling the effects of the observation on the behavior of the organization's members.

In qualitative research, according to Flick (2004), observation is methodologically systematized and applied by relying on non-participant observation, abstaining from field interventions and usually occurring in the natural environment of the observed events. In the context of film analysis and the inherent possibility of observing the scenes repeatedly, the observation protocol focuses on the consistent recording of data, albeit without aiming at standardization (cf. Cooper \& Schindler, 2011; Flick, von Kardoff \& Steinke, 2004; Gil, 2014; Yin, 2010).

Both approaches have been the object of comparative debates that have fueled a dichotomous perspective between them, making the qualitative approach the target of criticism about lack of rigor. Vieira (2004), for example, defended that a false dichotomy has been created by the simple argument that qualitative research is as scientifically rigorous as quantitative research. Chizzotti (2008), on the other hand, drew attention to the argument that researchers who carry out qualitative research recognize that the human experience is not confined to the nomothetic approach and decide to discover new investigative pathways without bypassing scientific rigor and objectivity.

According to Creswell (2010), however, those discussions have become less frequent, and there seems to be some degree of consensus around the singular steps of the qualitative approach. The value of this research approach resides in the specificity of the description and in the themes developed in the context of a specific location, thus privileging particularization, rather than generalization. Demo (2015), for example, believes in the exuberant future of the qualitative approach, despite the setbacks due to past criticisms.

As Chizzotti (2008) pointed out, the qualitative approach does not require that research presents a unique pattern because it allows for the fluent and contradictory aspects of reality. Thus, the research processes also depend on the plan, values, and objectives of the researcher. In this 
sense, the observations in the field and the researcher's intentions and frustrations or elations become data in themselves, constituting part of the interpretations that can be documented through the observation protocol (Flick, 2004). Moreover, the qualitative research approach works with the support of the plethora of meanings, motives, aspirations, beliefs, values, and attitudes that correspond to a deeper space of relationships, processes, and phenomena, which cannot be reduced to the operationalization of variables (Minayo, 2004).

In summary, the qualitative research approach can be viewed as a practical approach (e.g., Flick, 2002) to subject research questions to systematic examination (e.g., Demo, 2015), an effective approach in the social sciences in particular, given that the researcher studies the natural succession of actions (e.g., Gil, 2014). In the context of film analysis, it is emphasized that the choice for this approach occurs for two reasons (see Flick, 2002): (1) to provide the researcher with an orientation to the phenomenon to be investigated (see also Gil, 2014; Silva, 2010; Strauss \& Corbin, 2008; Vergara, 2010); and (2) to take into account contexts and meanings (see also Cooper \& Schindler, 2011; Denzin \& Lincoln, 2006; Flick et al., 2004). Thus, the approach is capable of supporting the researcher who uses films to account for the social construction of reality and the representations present in these films to make it possible to interpret different realities at different levels of meanings, whatever the organizations represented by the films (Flick, 2002).

\section{FUNDAMENTAL \\ CONSIDERATIONS}

Following Abbagnano's (2003, p. 437) definition of the phenomenological method as an approach to describe what is revealed, what underlies the phenomenological basis in film analysis is the search for extracting the meanings attributed by the subjects to the phenomenon under investigation, analyzing important statements and describing their essence. Based on Martins and Theóphilo (2009), it prioritizes qualitative evaluation because the phenomena have their own nature and represent starting points for research investigations. The qualitative evaluation, oriented to the extraction of meanings, leads to discovery in an exploratory, descriptive, and inductive way. Thus, the phenomenological method presumes to achieve the essence of the phenomenon, it is descriptive, and leads to specific results, but it is not limited to a passive description of the observed phenomenon.

With regard to the research strategy, it is contextualized that it can be characterized, a priori, as a case study carried out from secondary data. Based on systematic observations, the varied filmic languages enable understanding and learning that can constitute sources of evidence for data triangulation. Denzin (1989), for example, considered that: (1) in data triangulation, several sources with which the phenomenon is studied at different times (time), place (space), and people (informants) should be considered; (2) in the triangulation of researchers, different researchers study the phenomenon so that possible individual biases are minimized; and (3), in the theoretical triangulation, different perspectives are sought and different methods are used to study the same phenomenon (see also Vergara, 2012). Based on the benefits and contributions resulting from the use of triangulation, the possibilities in film analysis in the field of management are linked to: (1) data triangulation; (2) triangulation of researchers; triangulation of theories; and triangulation of methods.

Regarding the data collection strategy, the researcher uses the type of indirect, non-participant and second-hand observation, as characterized by Flick 
(2004), in which films or series are used as the locus of research. According to Cooper and Schindler (2011), although indirect observation is less flexible in relation to direct observation, it is also less biased, and can be more accurate. In addition, the permanent record can be reassessed. The possibility of observing the scenes repeatedly keeps the data record consistent in the observation protocol.

\section{BASIC CONSIDERATIONS IN FILM ANALYSIS}

In light of the impossibility of capturing a single truth perfectly, Rose (2011) considered the need to explain the methodological aspects used to collect, record, and analyze data from visual material. In addition to the necessity to substantiate each methodological aspect, as any other scientific approach, each observational study in film analysis requires justification of its relevance, with regard both to the object of observations itself (e.g., film or series) and to the reasons for the choice as the locus of research. Rose (2011) also alluded to the need to highlight theoretical and ethical foundations, as well as to decide on the unit of analysis. When using a series, for example, this decision becomes relevant in relation to the choice of season, if the series is not planned to be analyzed in its entirety.

$$
\text { Following Denzin (1989), }
$$

Champoux (1999), and Chizzotti (2003), among some advantages of the use of film analysis in educational and scientific activities (see also Banks, 2009; Cooper \& Schindler, 2011; Huczynski \& Buchanan, 2004; Mendonça \& Guimarães, 2008; Vanoye \& Galiot-Lèté, 1992) the following stand out: (1) increasing accessibility; (2) lower costs than those in field research; (3) possibility of extracting the visible and latent meanings (through a qualitative approach based on a valid observation protocol); (4) the possibility of visualizing concepts and theories in practice (especially in management); and (5) the ability to perform data collection iteratively (due to the ease of going back and forth between the scenes observed for analysis, as many times as necessary).

Film analysis also facilitates the understanding of texts and the application of theories in the field of management, allowing the operationalization of problematic variables in unstable contexts, due to factors such as time, direct interpersonal interactions, and sequence of actions. The contextualization of the locus of each observational study involving film analysis becomes essential, making clear the criteria of choice related to factors such as: (1) possibility of working with the chosen theme; (2) possibility of triangulation of evidence sources; (3) methodological aspects providing compatibility between data collection and analysis; and (4) possibilities of simulations in this field of management.

Regarding the descriptive nature of the research involving observational studies in film analysis, three aligned positions are recalled: (1) Godoy (1995) stated that the qualitative research is descriptive; (2) Vergara (2010) emphasized that, although it can serve as a basis for the explanation of phenomena, this tool is uncommitted to the need to explain such phenomena; (3) Gil (2014) reiterated that the objective of this tool, in essence, is to describe the chosen phenomenon through systematic observation directed to something that happens or has already happened.

The records to be made in observation protocols in film analysis (for case studies involving film analysis with observation protocols, see Champoux, 1999; Denzin \& Lincoln, 2006; Flick et al., 2004; Triviños, 2013), as described by Leite and Leite (2012), must be planned, taking into consideration: (1) sequential numbering of the scenes of the entire film or series; (2) indication of the start and end time of each scene; (3) description of the sequential scenes of the entire film or series; (4) character seen as the main focus of observation in each scene; (5) directly 
observable data shown in each scene; (6) indirectly observable data shown in each scene; (7) filmic languages presented in each scene; and (8) identified research constructs. The topics recorded in the resulting protocol correspond to the multiple sources of evidence, addressed as necessary for the case study (e.g., Yin, 2010).

After being recorded through the observation protocol, the data from the scenes of films or series, are analyzed using two strategies: (1) substantiating the theoretical proposals presented, which translates into advantages of ordering and focus on the initial questions of the research (e.g., Yin, 2010); and (2) interpreting and reflecting the data, mindful of the presence of the researcher's subjectivity and of the problematic nature of language and narrative in the processes of careful interpretation (e.g., Vergara, 2012).

\subsection{Essential steps in film analysis}

Table 1 - Guiding steps for conducting a film analysis

\begin{tabular}{|l|l|}
\hline Steps & \begin{tabular}{l} 
Guidelines \\
Consider the film (or series) in its entirety, writing down notable impressions, \\
\hline 2
\end{tabular} \\
\hline 3 & Formulate the research question to be sought in the film. \\
\hline 4 & $\begin{array}{l}\text { Conduct structured micro-analyzes of individual scenes and sequences, which } \\
\text { should lead to detailed descriptions and patterns in the exposure of these extracts. }\end{array}$ \\
\hline 5 & $\begin{array}{l}\text { Respond to the research question, in this search for standards extended to the entire } \\
\text { film. }\end{array}$ \\
\hline 6 & $\begin{array}{l}\text { Observe the realistic (literal) and subversive (with bias or prejudice) readings of } \\
\text { the film such that they are contrasted. }\end{array}$ \\
\hline 7 & Write a final interpretation. \\
\hline
\end{tabular}

Note. Source: Adapted from Denzin's (1989) text.

\section{6}

\section{.1 But why use it?}

From the teaching and learning and mentoring perspectives, film analysis is an
Based on Denzin (1989), Table 1 shows the essential steps for conducting a film analysis (see also Flick, 2004). From the choice of the locus of research, when conducting an observational study in film analysis, the data collection must follow a structure in which the set of steps in Table 1 makes it possible to translate the observations into organized information, which can subsidize the analysis, interpretation, and the discussion of the results. Amidst the value and singularities of the qualitative research approach, the importance of cautious and rigorous use of films or series is mirrored.

\section{CONCLUDING REMARKS}

Films represent an important locus of research. Film analysis has been receiving increased attention in recent years, seeing its use be extended to other audiovisual forms, such as television series. 
on concepts of competences, with a focus on co-responsibility to extract the knowledge collectively from the film. In Ipiranga (2007), groups of undergraduate students studying management and organizational behavior were guided to use film narratives (from nine films) as an instrument of formative action, using the classroom as a space for experiential learning (including social and affective dimensions) in the process.

In Leite et al. (2010), as another example, the effectiveness of tutorial education in the context of teaching and learning and research in management was studied through the analysis of the process of a group of mentees who were themselves learning to analyze a complete film that centered around the theme of tutorial education. Although the recording of those group members in action while learning via a tutorial process was possible, the premise was that observing other actors in action as many times as necessary would result in little to no discomfort (beyond the natural fatigue out of the persistent analysis). When compared to the alternative of observing themselves in action and the sense of embarrassment or the feeling of undue awareness that undoubtedly would follow, the use of film analysis was shown to be of tremendous advantages. When compared to non-experiential alternatives of reading about theoretical constructs and trying to incorporate most-effective strategies into their own behaviors while mentees, the advantages of choosing to use film analysis are just as clear.

From the research point of view, it makes it possible to study the phenomena portrayed in the films or series by reflecting upon the theoretical concepts related to the phenomena through systematic observation and analysis, encouraging scientific initiation. Matos et al. (2011), for example, used film analysis to study power in the scientific field with graduate students initiating their scientific inquiries. Leite et al. (2017) catalogued the use of 32 films over a period of three years both with undergraduate students initiating scientific work and with graduate students at master's and doctoral levels. In both cases, students benefited from a gradual strengthening of their ability to apply critical thinking to research inquiries in a systemic and experiential form.

Moreover, from the point of view of extension, the exhibition of films, combined with a proposal for a structured discussion of phenomena contained in these films, makes it possible to extend to the community the discussions developed and socialized at the university. Leite and Leite (2010), for example, discussed cases in which film analysis was used as aid to establish and strengthen workgroups, addressing how consultants and practitioners can use the tool to aid critical and systematic analysis of the specific realities of each context in organizations.

\subsection{And how to use it?}

Assuming a clearly formulated reason for the use of film analysis, following the steps laid out in Table 1 will be relevant for researchers who choose to carry out observational studies, as well as to educators considering incorporating the tool as an alternative to traditional methods and to practitioners considering incorporating its use in organizations.

Films and series have high scientific potential, especially those that reflect in their story the reality experienced by society and organizations. In this sense, it is an important locus of research, facilitating researchers' access to scenes that portray the complex environment of organizations and favoring the training of the researcher in the qualitative approach. Table 2 provides an overview of the broad range of management themes studied by scientific publications using film analysis in teaching and learning, research, and extension. 
Table 2 - Sample List of Scientific Publications Using Film Analysis since 2007 by Management Themes and Focus Activities

\begin{tabular}{l|ll}
\hline \multicolumn{1}{c}{ Publication } & \multicolumn{1}{c}{ Management Theme } & Focus Activities \\
\hline Fleury and Sarsur (2007) & Competency management. & $\begin{array}{l}\text { Teaching and learning/ } \\
\text { Research. }\end{array}$ \\
\hline Ipiranga (2007) & $\begin{array}{l}\text { People management } \\
\text { and organizational behavior. }\end{array}$ & $\begin{array}{l}\text { Teaching and learning/ } \\
\text { Research. }\end{array}$ \\
\hline Leite and Leite (2007) & Action theory. & Research. \\
Vergara (2007) & Organizational theory. & Teaching and learning. \\
\hline $\begin{array}{l}\text { Mendonça } \\
\text { and Guimarães (2008) }\end{array}$ & Teaching management. & $\begin{array}{l}\text { Teaching and learning/ } \\
\text { Research. }\end{array}$ \\
\hline Leite and Leite (2010) & Workgroups. & Research. \\
\hline $\begin{array}{l}\text { Leite, Leite, Nishimura and } \\
\text { Cherez, (2010) }\end{array}$ & Tutorial education. & $\begin{array}{l}\text { Teaching and learning/ } \\
\text { Research / Extension. }\end{array}$ \\
\hline Matos et al. (2011) & Power relations. & Research. \\
\hline Leite et al. (2012) & Observational studies in film analysis. & Research. \\
\hline Freitas and Leite (2015) & Communication. & Research. \\
\hline Bizarria et al. (2017) & Sustainability. & Research. \\
\hline Leite et al. (2017) & Pedagogical discourses. & Research Report. \\
\hline Aoki and Santos (2020) & Leadership. & Research. \\
\hline & & \\
\hline
\end{tabular}

Note. Source: Authors' research data (2021); in chronological order

Table 2 demonstrates that the application of the qualitative approach to the analysis of films or series has been an important path for the training of students and researchers. Observational studies in film analysis have been applied by undergraduate students to prepare Course Conclusion Papers and to carry out Scientific Initiation research, as well as by master's and doctoral students developing dissertations and theses. Moreover, the subject has great potential to attract the interests of researchers and professors in management, especially those who could use films as a basis for research or as didactic resources in the classroom.

\subsection{What can be accomplished}

The proposal to present the richness contained in the protocols for observing films or series used as a locus of research in observational studies in film analysis can stimulate the opening of spaces to proceed, with conceptual, methodological, and empirical improvements, both in research and in teaching and learning.

Considering the concrete contributions derived from observational studies in film analysis as the use of the tool has evolved, the following list can serve as a summary: (1) the use of films or series, as instruments of visual anthropology, constitutes a proposition to expresses succinctly a maxim concerning practical life; (2) the creation of an observation 
protocol specifically intended for film analysis is a must in carrying out research activities; (3) as a tool for qualitative analysis, film analysis is a legitimate scientific research strategy; (4) the increasing use of film analysis has contributed to revitalizing the teaching and learning and research processes in the field of management; (5) the use of film analysis can promote less charged readings of inconsistency, incompatibility, and incongruity in real actions by individuals, groups, educational institutions, and organizations, facilitating problem-solving and improvement in interpersonal dynamics; (6) the use of film analysis can help break down complex and diverse concepts in teaching, extension, and management activities; (7) the systematization of these observational studies can facilitate the activities of supervising professors and university students at undergraduate and graduate levels.

Concerning the qualitative, descriptive, inductive, interpretive and reflective character of its methodological aspects, these contributions can reach both the teaching researchers who wish to share such studies with their supervised students and those students who choose to start as researchers on this path. The aforementioned systematization and its resulting mentorship benefit has been observed through replications and extensions, reported in several conferences (and similar fora) and publications (e.g., peer-reviewed articles, book chapters), benefitting the training of new researchers. Other possibilities for theoretical, methodological, and empirical advances while using film analysis exist (e.g., applied to case studies), as long as rigor, transparency, and objectivity are favored, grounded on the understanding of why and how to use it.

\section{REFERENCES}

Abbagnano, N. (2003). Dicionário de filosofia [Philosophy dictionary]. São Paulo: Martins Fontes.

Aoki, V. C. G. \& Santos, S. S. S. (2020). Film analysis in management: A journey through the metaphors of the concept of leadership. Revista de Gestão, 27(2), 119-134.

Banks, M. (2009). Dados visuais para pesquisa qualitativa [Visual data for qualitative research]. Porto Alegre: Artmed.

Bizarria, F. P. A., Tavares, J. C. S., Brasil, M. V. O., Tassigny, M. M., \& Silva, M. A. (2017). O que um filme pode nos ensinar? Estudo observacional e análise do tema sustentabilidade no filme "Os Sem Floresta" [What can a movie teach us? Observational study and analysis of the sustainability theme in the film "Os Sem Floresta”]. Desenvolvimento em Questão, 15(40), 204-229.

Champoux, J. E. (1999). Film as a teaching resource. Journal of Management Inquiry, 8(2), 206-217.

Chizzotti, A. (2003). A pesquisa qualitativa em ciências humanas e sociais: evolução e desafios [Qualitative research in human and social sciences: Evolution and challenges]. Braga/Portugal: Revista Portuguesa de Educação 16(2), 221-236.

Chizzotti, A. (2008). Pesquisa qualitativa em ciências humanas e sociais [Qualitative research in human and social sciences]. Petrópolis: Vozes.

Cooper, D. R. \& Schindler, P. S. (2011). Métodos de pesquisa em Administração [Methods of research in the field of 
Administration]. Porto Alegre: Bookman.

Creswell, J. W. (2010). Projeto de pesquisa: métodos qualitativo, quantitativo e misto [Research project: qualitative, quantitative and mixed methods]. Porto Alegre: Artmed.

Demo, P. (2015). Metodologia do conhecimento científico [Methodology of scientific knowledge]. São Paulo: Atlas.

Denzin, N. K. (1989). The research act: $A$ theoretical introduction to sociological methods. Chicago: Aldine Publishing Company.

Denzin, N. K. (2004). Reading film: using films and videos as empirical social science material. In: Flick, U., von Kardorff, E., \& Steinke, I. A companion to qualitative research, 237-242. California. Thousand Oaks: Sage Publications.

Denzin, N. K. \& Lincoln, Y. S. (2006). O planejamento da pesquisa qualitativa: teorias e abordagens [Qualitative research planning: theories and approaches]. Porto Alegre: Artmed.

Fleury, M. T. L. \& Sarsur, A. M. (2007). O quadro negro como tela: o uso do filme Nenhum a Menos como recurso de aprendizagem em gestão por competências [The blackboard as a screen: the use of the film Not One Less as a learning resource in competency management]. Rio de Janeiro: CADERNOS EBAPE.BR, 5(1), 1-17.

Flick, U. (2002). Qualitative research: State of the art. Sage Publications, 41(1), 5-24.
Flick, U. (2004). Uma introdução à pesquisa qualitativa [An introduction to qualitative research]. Porto Alegre: Bookman.

Flick, U., von Kardoff, E., \& Steinke, I. (2004). What is qualitative research? An introduction to the field. In: Flick, U., von Kardorff, E., \& Steinke, I. A companion to qualitative research, 3-11. California. Thousand Oaks: Sage Publications.

Freitas, A. D. G. \& Leite, N. R. P. (2015). Linguagem fílmica: uma metáfora de comunicação para a análise dos discursos nas organizações [Filmic language: a communication metaphor for discourse analysis in organizations]. São Paulo: Revista de Administração - RAUSP, 50(1), 89-104.

Gil, A. C. (2014). Métodos e técnicas de pesquisa social [Methods and techniques of social research]. São Paulo: Atlas.

Godoy, A. S. (1995). Introdução à pesquisa qualitativa e suas possibilidades [Introduction to qualitative research and its possibilities]. São Paulo: Revista de Administração de Empresas-RAE, 35(2), 57-63.

Huczynski, A. \& Buchanan, D. (2004). Theory from fiction: a narrative process perspective on the pedagogical use of feature film. Journal of Management Education, 28(6), 707-726.

Ipiranga, A. S. R. (2007). A narração fílmica no ensino de gestão de pessoas e de comportamento organizacional [Film narration in teaching people management and organizational behavior]. In: Davel, E., Vergara, S. C., \& Ghadiri, D. P. (Orgs.) Administração com arte: 
experiências vividas de ensinoaprendizagem [Administration with art: lived teaching-learning experiences], 81-91. São Paulo: Atlas.

Jones, M. (2014). Researching organizations: The practice of organizational fieldwork. Los Angeles/London/New

Delhi/Singapore /Washington DC: SAGE.

Leite, N. R. P., Amaral, I. G., Freitas, A. D. G., \& Alvarenga, M. A. (2012). Projetos educacionais e estudos observacionais em análise fílmica: qual o atual status de produção no Brasil? [Educational projects and observational studies in film analysis: what is the current status of production in Brazil?] São Paulo: Revista de Gestão e Projetos - GeP, 3(3), 215-250.

Leite, N. R. P. \& Leite F. P. (2007). Um estudo observacional do filme 'Denise está Chamando' à luz da Teoria de Ação de Chris Argyris e Donald Schön [Study of the motion picture "Denise Calls Up" focusing on the action theory by Chris Argyris and Donald Schön]. São Paulo: Revista de Gestão da REGE USP, (especial), 77-91.

Leite, N. R. P. \& Leite, F. P. (2010). A linguagem fílmica na formação e no fortalecimento de grupos, equipes e times de trabalho: aplicações do estudo observacional [The role of filmic language in the establishment and strengthening of workgroups: observational study applications]. São Paulo: Revista de Gestão REGE USP, 17(1), 75-97.

Leite, N. R. P. \& Leite F. P. (2012). Protocolo de observações para o processo de coleta e análise de dados oriundos de filmes comerciais, sob a égide dos estudos observacionais no processo de ensino-aprendizagem e pesquisa em Administração [Observation protocol for collecting and analyzing data from commercial films, under the auspices of observational studies in the teaching-learning process and research in management]. (Technical Production.)

Leite, N. R. P., Leite F. P., Gardini, A. P. S., Nishimura, A. T., Silva, C. C., Amaral, I. G., Novaes, J. R. T. C., \& Silva, M. A. B. (2017). Processo de ensino-aprendizagem e pesquisa em administração: lições a partir da análise de discursos pedagógicos [Teaching-learning process and management research: lessons from the analysis of pedagogical discourses]. (Research Report.)

Leite, N. R. P., Leite, F. P., Nishimura, A. T. \& Cherez, R. L. (2010). Educação tutorial: revitalizando ensino-aprendizagem e pesquisa em Administração [Tutorial education: revitalizing teaching-learning and research in Management]. Belo Horizonte: Revista de Administração FACES, 9(4), 87104.

Leite, N. R. P., Nishimura, A. T., Silva, M. A. B., \& Santos, E. G. (2021). Análise fílmica em Administração: dos processos de insipiência e incipiência até as elucidações em seus aspectos conceituais, metodológicos e de aplicação [Film analysis in Management: from incipient processes to clarifications in their conceptual, methodological and application aspects]. In preparation. 
Loizos, P. (2011). Vídeo, filme e fotografias como documentos de pesquisa [Video, film and photographs as research documents]. In: Bauer, M. W. \& Gaskell, G. Pesquisa Qualitativa com texto, imagem e som: um manual prático [Qualitative research with text, image and sound: a practical manual]. Rio de Janeiro: Vozes.

Matos, F. R. N., Lima, A. C., \& Giesbrecht, C. M. (2011). Estudo observacional das relações de poder no filme ' $O$ Óleo de Lorenzo' [Observational study of power relations in the film 'The Oil of Lorenzo']. Rio de Janeiro: CADERNOS EBAPE.BR, 9(2), artigo 11, 438-449.

Martins, G. A. \& Theóphilo, C. R. (2009). Metodologia da investigação científica para ciências sociais aplicadas [Scientific research methodology for applied social sciences]. São Paulo: Atlas.

Mendonça, J. R. C. \& Guimarães, F. P. (2008). Do quadro aos "quadros": o uso de filmes como recurso didático no ensino de administração [From the board to the "frames": the use of films as a didactic resource in teaching management]. Rio de Janeiro: CADERNOS EBAPE.BR, 6(especial), 1-21.

Minayo, M. C. (Org). (2004). Pesquisa social: teoria, método e criatividade [Social research: theory, method and creativity]. Petrópolis, RJ: Vozes.

Napolitano, M. (2013). Como usar o cinema na sala de aula [How to use cinema in the classroom]. São Paulo: Contexto.
Rose, D. (2011). Análise de imagens em movimento [Moving image analysis]. In: Bauer, M. W. \& Gaskell, G. Pesquisa qualitativa com texto, imagem e som: um manual prático [Qualitative research with text, image and sound: a practical manual]. Rio de Janeiro: Vozes.

Severino, A. J. (2016). Metodologia do trabalho científico [Scientific work methodology]. São Paulo: Cortez.

Silva, A. B. (2010). A fenomenologia como método de pesquisa em estudos organizacionais [Phenomenology as a research method in organizational studies]. In: Godoi, C. K., Bandeirade-Melo, R., \& Silva, A. B. (Orgs.). Pesquisa qualitativa em estudos organizacionais: paradigmas, estratégias e métodos [Qualitative research in organizational studies: paradigms, strategies and methods]. São Paulo: Saraiva.

Strauss, A. \& Corbin, J. (2008) Pesquisa qualitativa: técnicas procedimentos para $\mathrm{O}$ desenvolvimento de teoria fundamentada [Qualitative research: techniques and procedures for the development of grounded theory]. Porto Alegre: Artmed.

Triviños, A. N. S. (2013). Introdução à pesquisa em Ciências Sociais: a pesquisa qualitativa em Educação [Introduction to Social Science research: qualitative research in Education]. São Paulo: Atlas.

Vanoye, F. \& Goliot-Lèté, A. (1992). Précis d'analyse filmique [Precise film analysis]. Paris: Éditions Nathan. 
Vanoye, F. \& Goliot-Lèté, A. (2012). Ensaio sobre análise fílmica [Essay on film analysis]. Campinas, SP: Papirus.

Vergara, S. C. (2007). Arte cenográfica, vídeos, dramatizações e música no ensino de teoria das organizações [Scenographic art, videos, dramatizations and music in teaching organizational theory]. In: DaveL, E., Vergara, S. C., \& Ghadiri, D. P. (Orgs.) Administração com arte: experiências vividas de ensinoaprendizagem [Administration with art: lived teaching-learning experiences], 277-286. São Paulo: Atlas.

Vergara, S. C. (2010). Projetos e relatórios de pesquisa em Administração
[Projects and research reports in Administration]. São Paulo: Atlas.

Vergara, S. C. (2012). Métodos de pesquisa em Administração [Methods of research in the field of Administration]. São Paulo. Atlas.

Vieira, M. M. F. (2004). Por uma boa pesquisa (qualitativa) em Administração [For good (qualitative) research in management]. In: Vieira, M. M. F. \& Zouain, D. M. Pesquisa qualitativa em administração [Qualitative research in Management], 13-28. Rio de Janeiro: FGV.

Yin, R. (2010). Estudo de caso: planejamento e métodos [Case study: planning and methods]. São Paulo: Bookman.

\footnotetext{
i Nildes Raimunda Pitombo Leite

Professora Adjunta do Departamento Acadêmico de Administração, Campus Osasco - Unifesp

ii Fábio Pitombo Leite

Associate Professor, Department of Psychology, Lima Campus, The Ohio State University

iii Augusto Takerissa Nishimura

Professor Coordenador da Área de Gestão de Negócios do Centro Universitário das Américas-FAM

iv Marco Antonio Batista da Silva

Professor do Instituto Federal de Educação, Ciência e Tecnologia do Sul de Minas

Gerais-Campus Avançado Carmo de Minas-IFSul de Minas

v Emerson Gomes dos Santos

Professor Adjunto do Departamento Acadêmico de Administração, Campus

Osasco Unifesp
} 